\title{
РЕЦЕНЗІЯ
}

\section{ХИМЕРНІ НЬЯНДУТІ РОМАНУ ХУАНА МАНУЕЛЯ МАРКОСА «ЗИМА ІЮНТЕРА»»}

\author{
(Хуан Мануель Маркос «Зима Гюнтера»-Роман. Переклад з іспанської : Ігор Проченко, Ярослав \\ Губарєв. Київ : Талком, 2014. 244c.).
}

Роман сучасного парагвайського митця Хуана Мануеля Маркоса «Зима Гюнтера» - це складне плетиво із національної історії Парагваю, магічного реалізму, інтелектуальної прози, широкого літературного інтертексту, політичного дискурсу та щирого патріотизму. Прагнення виразити себе і свою позицію в умовах політичної диктатури спричинило звернення автора до іносказання, до прямого залучення уривків 3 інших художніх творів та історичних текстів, до міфу, легенди i, нарешті, до техніки мимовільного письма. Магія, перевтілення, ритуал, симбіоз реального й уявного - це не лише данина традиції латиноамериканської літератури, це і вираження того особливого світовідчуття, що успадковане 3 фольклорної спадщини, $з$ народного тлумачення світу та буття. У вишуканій манері різнопланового наративу, що ведеться то від осіб персонажів, то від наратора, то від автора, змальовано долі парагвайців за часів диктатури генерала Стресснера з аналептичними рефлексіями про минуле країни.

Складний і напружений сюжет роману охоплює реалії не лише політичного життя Парагваю другої половини XX століття, але й Свропи (Іспанії, Румуніiі), США, а також пророчі сказання караїв, міфи та легенди індіанців гуарані. Автор ефективно використовує техніку потоку свідомості, ретроспекцію, фрагментовану нарацію, компресію часу і химерні повороти магічного реалізму, коли зникає межа між уявним та реальним, між маскою та справжнім обличчям. Крім того, вражає багатство художньої мови (відчутне навіть у перекладі), складна метафорика і загалом закоханість автора у слово. Фрагменти потоку свідомості, передані без розділових знаків і великих літер, що забезпечує ефект плинності думок, їхню хаотичність та непослідовність, інтенсифікують невимовність в одному випадку страждання, в іншому - туги, а ще в іншому - жалю і печалі.

У центрі твору доля двох молодих дівчат: Соледад Монтоя Санабрія та Вероніки Сарріа-Кірога, які намагаються протистояти тоталітарному режимові. Обидві навчаються в елітному коледжі для черниць. Перша організувала студентський бунт, пише складні вірші і читає твори марксистів. Соледад живе 3 хворою матір'ю; батько, колись власник відомої перукарні, давно помер. Вероніка - донька багатої і шанованої в Коррієнтес родини, іії дід -полковник і національний герой. Мати дівчини, Еліза, страждає на галюцинації і вважає себе Елізою Лінч - ірландською повією, яка була коханкою парагвайського диктатора Солано Лопеса. При цьому наратив роману рясніє висловлюваннями Лопеса про долю батьківщини. В одному з них він розмірковує про взаємини із США: «...я з болем думаю про те, як цей зарозумілий імперський гігант може повестися 3 нашим народом. Наша впевненість у безвихідності нашої ситуації заважає нам досягти чесної домовленості. Янкі вірні своїй традиції демонструвати силу, брякаючи зброєю. Вони не здатні до мирних переговорів» (с. 69). Через зображення безпомічності Парагваю автор передає становище багатьох малих держав, що потрапили в економічну та культурну кабалу до великих імперій.

Соледад та Вероніка належать до покоління нових парагвайців, яке намагається змінити країну. Задушливого літнього дня, коли дівчата читають «Феноменологію духа» Гегеля, між ним виникає інтимна близькість, що з розгортанням сюжету роману переросте у кохання. Їхні відносини розвиваються на тлі політичної диктатури, загальної суспільної нетерпимості до будь-яких проявів інакодумства, етнічної нетолерантності, зокрема до євреїв, та суворого духу католицизму. Кохання дівчат - своєрідний бунт проти системи та глибоко патріархального світогляду. У мереживо другої частини твору густо вплетені уривки з листів Соледад, яку безпідставно підозрюють у вбивстві і яка перебуває у в'язниці, до Вероніки. Автор оздоблює епістолярій дівчини прямими покликами на відомі 
твори Брехта, Елюара, де Ліберо, Лорки, Сернуди, Гільєна, Сервера, Вальєхо та низки інших майстрів слова, що слугують епіграфами. Кожен лист - це прониклива інтерпретація окремого цитування, що наче випробуване гірким досвідом тортур у неволі. Вражає емоційна насиченість кожного рядка, який вже сам по собі є згустком багатої поетичної уяви та сили. Поезія душі дівчини оприявлена на сторінках листів розкішним стилем, що вкорінений у вишуканому красномовстві традиції латиноамериканської літератури. Зрідка в епоху постмодерної іронії та підозри до щирості надибуємо в сучасній художній словесності такі рядки: «Якби у мене не було цього кохання, я б його вигадала. Жодна людина не може жити без цього полум'я. Ніхто не може обманювати себе, як сліпий від народження не може уявити собі неймовірну красу сонця, що встає. Ця любов дала мені силу перенести всі випробовування - серед мук і болю, прицвяшена до ганебного стовпа, вигнана зі світу, переслідувана, зганьблена, зранена погрозами, самотня, як загадка, яку не хочуть відгадувати, посаджена до клітки стерв'ятниками, які бояться сонячного світла» (с. 187).

Уособленням старого ладу і світобачення є батько Вероніки, Еварісто, який передчуває близький крах старої системи. Зміни в його родині, а саме син Альберто, який «не навчився розрізняти національності і прізвища, оточив себе безіменними типами 3 сумнівною репутацією, по-бабськи відпустив волосся до плечей, говорить як вантажник» (с.46), донька, яка не слухає його, виходить сама гуляти, читає марксистську літературу і запросила подругу жити 3 нею, шизофренічна дружина - усі ці моменти сигналізують про кінець його традиційного укладу життя.

До коледжу, де навчаються дівчата, приїжджають викладати два американські професори - Еліза Гюнтер, дружина парагвайця Гюнтера, відома в США дослідниця-іспаністка, яка написала дисертацію по творчості Мачадо, та iï друг, Асуага, викладач з університету в Оклахомі. Американці усвідомлюють безправність та страх. Вони намагаються допомогти молодим бунтарям. Коли заарештовують Соледад, Еліза просить свого впливового чоловіка допомогти дівчині, яка, крім того, є його племінницею. Із цим поворотом у подіях виникає ще одна важлива сюжетна лінія, а саме переосмислення Гюнтером, успішним бізнесменом і банкіром, власної ідентичності, його трансформація, що зрештою спричинює повернення до своєї сутності, до рідного краю і до зречення від розкоші та марнославства багатого світу. Зима, що іiі він змушений провести у Коррієнтес, розвінчує його зачарування США і повертає до краю, якого він намагався зректися і забути.

Асуага з учнями коледжу ставить частину п'єсу Юджина О’Ніла «Жалоба пасує Електрі», що має назву «Переслідувані». Проте постановники вирішили дещо змінити твір драматурга і зіграти у стилі давньогрецького театру в масках. Під час показу вистави стається вбивство Ларраїна, який якимсь чином успадкував усе майно родини Сарріа-Кірога. У вбивстві підозрюють усіх, хто заважає політичній диктатурі. Невинних дівчат запроторюють за грати. Проте убивцю так і не знаходять, адже це був таємничий ягуар, що вистрибнув у вікно. Поєднання реального і уявного, театрального дійства та реального вбивства, магії та звичайного перевдягання забезпечує сюжетну напругу та густий смак латиноамериканського письма.

Гюнтер, голова Всесвітнього банку, повертається в Коррієнтес, щоб якось порятувати єдину племінницю. Проте по приїзді розуміє, що потрапив у іншу реальність, у простір деспота, який нікого не слухає. Він зустрічається із впливовими людьми, але очевидно, що влада грошей поступається владі диктатора. Цей критичний момент переривається уривком з листа Соледад, насиченого почуттям великої любові до рідного краю: «Я повинна покинути тебе, батьківщино моя, можливо надовго. Зрозумій мене, я йду не за власним бажанням, мене відривають від твоєї землі. Але я візьму з собою твоїх птахів і дерева, твої ріки, параболу твоєї веселки, наші з тобою надії, твої печалі й вуста. I знову я буду кричати твоє ім'я, я понесу з собою твої яскраво-червоні знамена, щоб в моєму обличчі впізнавали тебе» (с.201).

Жорстокість, насилля, терор, безпідставні звинувачення, безправність, з одного боку, протиставлені щирості почуттів, любові до рідної землі, повазі до подвигу, коханню. Оптимізму надає одне 3 тверджень роману: «Одного разу хтось зрозуміє, що в людях більше добра, ніж зла, що людський рід схожий на старого рибалку, що бореться з акулами й самотністю у відкритому морі» (с. 71). Минають епохи, минають тирани, минає набута розкіш і надумані цінності, залишається щирість, справжні почуття і таємничість буття, закарбована в магії й мiфi. 